\title{
De berechting binnen een redelijke termijn
}

\author{
Een empirisch onderzoek naar doorlooptijden in handelszaken
}

\author{
Remme Verkerk, Frans van Dijken Dewy Pistora*
}

\section{Inleiding}

Deze bijdrage ziet op een van de fundamentele beginselen van het civiele proces: de berechting binnen een redelijke termijn. ${ }^{1}$ Volgens de wetgever dienen procedures 'op de eerste plaats vlot te verlopen willen zij aan de maatschappelijke eisen van de tijd en aan de eisen van een goede rechtspraak voldoen'. ${ }^{2}$ De ratio daarachter is dat geen recht wordt gedaan indien een gerechtelijke procedure zich jaren voortsleept: 'justice delayed is justice denied'. ${ }^{3}$ Zowel de rechter als de procespartijen zijn verantwoordelijk voor een voortvarende behandeling. ${ }^{4}$

De gerechten hanteerden lange tijd als norm dat $70 \%$ van de handelszaken binnen één jaar en $90 \%$ binnen twee jaar zouden moeten worden beslecht. Inmiddels lijkt te worden uitgegaan van stringentere standaarden en doelstellingen, waaruit volgt dat ook complexe zaken in beginsel per instantie binnen één jaar worden afgerond. ${ }^{5}$ Men moet dergelijke doelstellingen niet verwarren met de minimumnormen die voort-

\footnotetext{
Mr. dr. R.R. Verkerk is werkzaam als cassatieadvocaat bij Houthoff en als hoofddocent burgerlijk procesrecht aan de Universiteit Utrecht. Dr. F. van Dijk is werkzaam als hoogleraar empirische analyse van rechtssystemen aan de Universiteit Utrecht. Hij is tevens verbonden aan de Raad voor de rechtspraak. D. Pistora is onderzoeksassistent aan de Universiteit Utrecht.

De auteurs danken het Landelijk Dienstencentrum van de Rechtspraak, en in het bijzonder Egon Meeuwisse, voor de toegang tot en ontsluiting van de data.

1. Zie art. 6 EVRM en art. 47 Handvest EU. Voor een overzicht zie o.m. P. Smits, Artikel 6 EVRM en de civiele procedure (Burgerlijk Proces \& Praktijk nr. 10), Deventer: Kluwer 2008, hoofdstuk 5 en Asser Procesrecht/Giesen 12015 , hoofdstuk 9.

2. Parl. Gesch. Herz. Rv, p. 6 (MvT). Zie ook Parl. Gesch. Vereenv. en Dig. Burg. Procesrecht, p. 21 (MvT). Zie voor een historisch overzicht o.m. A.W. Jongbloed, 'Attempts to accelerate Dutch civil procedure in the nineteenth and twentieth centuries', in: C.H. van Rhee (red.), The law's delay. Essays on undue delay in civil litigation, Antwerpen: Intersentia 2004, p. 141 e.v.

3. Vertragingen ondermijnen het vertrouwen in de rechtspraak. Zie bijv. EHRM 30 oktober 2012, zaak 40150/09, EHRC 2013/16 (Glykantzi) Griekenland), r.o. 75.

4. Zie o.m. art. 20 Rv, Parl. Gesch. Herz. Rv, p. 133: 'gezamenlijke verantwoordelijkheid'. Zie in algemene zin ook W.D.H. Asser e.a., Uitgebalanceerd. Eindrapport fundamentele herbezinning Nederlands burgerlijk procesrecht, Den Haag: Boom Juridische uitgevers 2006, p. 52, B.T.M. van der Wiel, De rechtsverhouding tussen procespartijen, Deventer: Kluwer 2004, p. 74 e.v. en T. van der Linden, 'In de hoogste versnelling. Over de invloed die partijen hebben op de doorlooptijd van een civiele procedure', NJB 2020/1318.
}

vloeien uit onder meer art. 6 EVRM. De maximale 'redelijke termijn' van art. 6 EVRM laat zich lastig in een vast aantal maanden uitdrukken. Of de doorlooptijden in een concreet geval redelijk zijn, hangt onder andere af van de complexiteit van de zaak, de handelwijze van partijen en die van de gerechtelijke instanties. ${ }^{6}$ In de Nederlandse rechtspraak en literatuur wordt doorgaans aangenomen dat een civiele procedure in één instantie in beginsel uiterlijk binnen twee jaar moet worden afgerond. ${ }^{7}$

De Nederlandse civiele rechtspleging functioneert internationaal bezien vrijwel over de gehele linie goed. ${ }^{8}$ Ook als het gaat om de berechting binnen een redelijke termijn zijn er pluspunten te benoemen. Ons rechtssysteem voorziet in spoedprocedures indien haast geboden is. ${ }^{9}$ Sommige veelvoorkomende categorieën van zaken worden vrijwel altijd binnen enkele maanden afgedaan. ${ }^{10}$ Uit klantwaarderingsonderzoeken, ${ }^{11}$ enquêtes onder ondernemers ${ }^{12}$ en de juridi-

5. Jaarverslag Rechtspraak 2019, par. 1.2 'Tijdige rechtspraak', onder verwijzing naar J. Mendlik e.a., Doorlooptijden in beweging. Eindrapport project doorlooptijden Rechtspraak, definitieve versie, oktober 2019, beschikbaar via www.rechtspraak.nl.

6. Zie bijv. het standaardarrest EHRM 25 juni 1987, ECLI:NL:XX: 1987:AC9931 (Capuano/Italië). Zie uitvoerig Asser Procesrecht/Giesen $12015 / 397$ e.v. en F. Calvez \& N. Regis, Length of court proceedings in the member states of the Council of Europe based on the case law of the European Court of Human Rights, European Commission for the Efficiency of Justice (CEPEJ), 2018, beschikbaar op www.coe.int.

7. Zie bijv. CRvB 26 januari 2009, ECLI:NL:CRVB:2009:BH1009, JB $2009 / 66$, r.o. 3.5. Giesen meent dat het voor de hand ligt ook in civiele zaken bij de termijn van twee jaar aan te sluiten. Asser Procesrecht/Giesen 1 2015/404. Zie ook de Rechtspraak, Kengetallen gerechten 2018, beschikbaar op www.rechtspraak.nl, par. 3.2.2.

8. In de ranglijst van het World Justice Project Rule of Law Index 2020 stond de Nederlandse civiele rechtspleging op een goede derde plek. De score op het onderdeel 'no unreasonable delay' is echter verreweg het minst positief. Zie worldjusticeproject.org, p. 114.

9. Zie in algemene zin J.W. de Groot, 'Spoedprocedures', TCR 2018, afl. 4, p. 93 e.v. Zie R.J.J. Eshuis \& B.J. Diephuis, Factsheet 18-1. Civiele rechtspraak, 2018, beschikbaar op www.wodc.nl, figuur 14 voor cijfers over doorlooptijden in kortgedingprocedures.

10. Uit statistische gegevens blijkt dat o.m. verstekzaken, WSNP-zaken en beheerszaken vrijwel altijd binnen drie maanden worden afgerond. Zie o.m. R. van Os \& M. Smit, Civielrechtelijke appelrechtspraak, een ciffermatige verkenning (Cahier 2016-9), Den Haag: WODC 2016, p. 38. Zie ook Eshuis \& Diephuis 2018, p. 14-16. 
sche literatuur ${ }^{13}$ volgt evenwel dat juist ten aanzien van de doorlooptijden in civiele zaken het nodige valt te verbeteren.

De Rechtspraak heeft zichzelf tot doel gesteld om de gemiddelde doorlooptijden fors te reduceren. ${ }^{14}$ In jaarplannen van de Rechtspraak wordt dit al jarenlang als het belangrijkste speerpunt genoemd. ${ }^{15}$ Voor een recent initiatief dat in dit kader is ontplooid, kan worden gewezen op het eindrapport Doorlooptijden in beweging, waarop de hiervoor gememoreerde nieuwe standaarden zijn gebaseerd. Het rapport bevat talloze suggesties om de doorlooptijden te verbeteren. Zo wordt voorgesteld maximale termijnen te hanteren voor onder meer het verweer, de zitting, bewijsverrichtingen en de uitspraak. ${ }^{16}$ In Nederland lijkt de laatste jaren ondanks de vele initiatieven geen voortgang te zijn geboekt. ${ }^{17}$ Een recente studie naar de duur van de civiele procedure in vijf landen laat zien dat

11. Klantwaardering Rechtspraak 2017, landelijk rapport d.d. 20 november 2017, beschikbaar op www.rechtspraak.nl, p. 15: 'Het belangrijkste verbeterpunt is met stip de doorlooptijd van de volledige procedure, vanwege de grote ontevredenheid en aanzienlijke impact op de algemene tevredenheid.'

12. Zie T. Geurts \& M.J. ter Voert, Geschillen in het MKB (Cahier 2019-11), Den Haag: WODC 2019, p. 42, 53 en 80. In figuur 44 is weergegeven dat $73 \%$ van de ondernemers die betrokken waren bij een geschil van oordeel was dat procedures tijdrovend zijn, in totaal $18 \%$ oordeelde: 'weet niet'.

13. In de literatuur wordt o.m. kritiek geuit over het ontbreken van een adequate remedie om de berechting binnen een redelijke termijn te waarborgen (zie m.n. EHRM 26 oktober 2000, ECLI:NL:XX: 2000:AD5181, NJ 2001/594, m.nt. E.A. Alkema (Kudla/Polen)). Aangekondigde wetgeving is uitgebleven, zie Stb. 2013, 162, p. 4. Zie o.m. J. van de Bunt, 'Overschrijding van de redelijke termijn in civiele zaken', NJB 2019/252, Asser Procesrecht/Giessen 1 2015/421, E. Bauw, 'Kansen voor versnelling van civiele procedures', in: M.N. Boeve \& R. Uylenburg (red.), Kansen in het omgevingsrecht, Groningen: Europa Law Publishing 2010, p. 405-414, p. 405, en de conclusie en annotatie bij HR 28 maart 2014, ECLI:NL:HR:2014:736, NJ 2014/525, m.nt. P.C.E. van Wijmen en W.D.H. Asser (De Bilt).

14. Zie bijv. de Agenda van de Rechtspraak 2015-2018, beschikbaar op www.rechtspraak.nl. De eerste doelstelling luidde: 'In 2018 duren rechtszaken 40\% korter dan in 2013.' Zie voor een kritische bespreking M.J.A.M. Ahsmann \& H.F.M. Hofhuis, 'Versnelling van de doorlooptijden van rechtszaken met $40 \%$. Realistisch of Haagse bluf?', NJB 2014/1273, M.J.A.M. Ahsmann, 'Het dilemma van een rechter: over werkdruk, uitspraakdatum en kwaliteit', TvPP 2019, afl. 2, p. 37 en 38 en J. Ekelmans, In eerste aanleg (Burgerlijk Proces \& Praktijk nr. 16), Deventer: Wolters Kluwer 2015, nrs. 112 en 113.

15. Zie bijv. de Rechtspraak, Jaarplan 2020, p. 6.

16. Mendlik e.a. 2019, p. 119

17. Zie voor cijfers over de afgelopen vijf jaar het Jaarverslag Rechtspraak 2019 en zie voor een kwalitatieve beschouwing J. Sylvester e.a., Rapport visitatie gerechten 2018, Den Haag 2019, beschikbaar op www.rechtspraak.nl, par. 3.2: '(...) niet of nauwelijks (...) verbeterd.' Zie ook het jaarplan van de Rechtspraak voor 2019, alwaar wordt gewezen op een 'weerbarstige praktijk', waardoor in de voorafgaande jaren rechtspraakbreed 'weinig structureel verbeterd' is. Zie www.rechtspraak.nl. handelszaken met een financieel belang boven $€ 1$ miljoen elders veel vlotter worden afgewikkeld. ${ }^{18}$

Er is empirisch onderzoek verricht naar doorlooptijden in civiele zaken. Het meest uitvoerige statistische onderzoek naar doorlooptijden in eerste aanleg treft men aan in de dissertatie van Eshuis uit 2007. Hij heeft de doorlooptijden nauwkeurig in beeld gebracht en in het bijzonder ook gekeken naar de vraag welke interventies ertoe bijdragen dat de doorlooptijden afnemen. Hij concludeert onder andere dat de doorlooptijden in civiele zaken in hoge mate bepaald worden door de werkvoorraad en het aantal formatieplaatsen bij de rechtbanken. Eshuis wijst ook op het belang van het bewerkstelligen van een cultuuromslag bij zowel advocaten als rechters, in die zin dat gezamenlijke opvattingen en verwachtingen over onder meer de termijnen en nader uitstel aanpassing behoeven. ${ }^{19}$ Naast het werk van Eshuis kan worden gewezen op de nodige andere empirische onderzoeken, waarin onder meer is ingegaan op de actuele doorlooptijden, ${ }^{20}$ de doorlooptijden in kantonzaken, ${ }^{21}$ de doorlooptijden in hoger beroep, ${ }^{22}$ alsook de (economische) gevolgen van lange doorlooptijden. ${ }^{23}$ Kwantitatieve gegevens die rekening houden met de diversiteit van civiele procedures en tevens inzicht geven in de verschillende fasen van de procedure zijn helaas nog altijd in (te) beperkte mate voorhanden. Dat is problematisch, omdat het zonder empirische gegevens lastig is om goed beleid vorm te geven. ${ }^{24}$

Dit artikel beoogt een bijdrage te leveren aan het empirisch onderzoek naar de doorlooptijden in het civiele proces. Daartoe wordt in het bijzonder gekeken naar die categorieën van zaken die te kampen hebben met de langste doorlooptijden: handelszaken met een belang van boven de $€ 1$ miljoen. Wij hebben - kort samengevat - ruim honderd recente handelszaken met een initiële financiële claim tussen $€ 1$ miljoen en $€ 5$ miljoen waarin hoger beroep is ingesteld onderzocht. Van

18. C. Costello, F. van Dijk, S. Giorgi, L. Griskevic, F. Holm, W. Storhaug Larssen, S. Sicking \& N. Meilutis, Economic value of the judiciary; A pilot study for five countries on volume, value and duration of large commercial cases. Preliminary report, ENCJ/Utrecht University 2020, www.encj.eu/ node/563. Zie voorts Van Rhee 2004 en A.S. Zuckerman, Civil justice in crisis. Comparative perspectives of civil procedure, Oxford: Oxford University Press 2000, CEPEJ, European judicial systems. Efficiency and quality of justice, Straatsburg: European Council Publishing 2016, beschikbaar op www.coe.int, S.D. Djankov e.a., Courts: The Lex Mundi project (NBER working paper 8890), Cambridge 2002 en M. Dakolias, 'Court performance around the world: A comparative perspective', Yale Human Rights and Development Journal (2) 1999, p. 87-142.

19. R.J.J. Eshuis, Het recht in betere tijden. Over de werking van interventies ter versnelling van civiele procedures (diss. Rotterdam; O\&B 254), Den Haag: Boom Juridische uitgevers/WODC 2007. Zie hierover o.m. R. de Bock, 'Het recht in betere tijden', $A A$ 2020, p. 564.

20. Zie bijv. Eshuis \& Diephuis 2018. Zie ook de Rechtspraak, Kengetallen gerechten 2018, par. 3.2.

21. K. van der Kraats, De eigen (aardig) heid van de kantonrechter, Den Haag: Boom juridisch 2017, par. 5.4.

22. Van Os \& Smit 2016.

23. F. Felso e.a., De tijd loopt door: de gevolgen van lange doorlooptijden in de rechtspraak, Den Haag/Amsterdam: WODC/SEO Economisch Onderzoek 2007. Zie ook E. Bauw \& F. van Dijk, 'Tijdigheid van rechtspraak in maatschappelijk perspectief, Rechtstreeks 2005, afl. 2, p. 50-68, par. 3.

24. Zie ook Ahsmann \& Hofhuis 2014. 


\begin{tabular}{lcrrr}
\hline & Eerste anleg & \multicolumn{2}{c}{ Hoger beroep } \\
Hoogte van de vordering in $€$ & Volume & Tijd & Volume & Tijd \\
\hline $0<c<1.000$ & 268.500 & 20 & 33 & 386 \\
$1.000 \leq c<10.000$ & 86.450 & 52 & 746 & 432 \\
$10.000 \leq c<100.000$ & 17.360 & 166 & 1.510 & 501 \\
$100.000 \leq c<1.000 .000$ & 2.869 & 346 & 688 & 592 \\
$1.000 .000 \leq c<5.000 .000$ & 388 & 513 & 141 & 661 \\
$5.000 .000 \leq c<10.000 .000$ & 65 & 527 & 20 & 601 \\
$10.000 .000 \leq c<20.000 .000$ & 27 & 478 & 12 & 557 \\
$20.000 .000 \leq c<100.000 .000$ & 25 & 667 & 10 & 629 \\
$c \geq 100.000 .000$ & 11 & 731 & 2 & 764 \\
Waarde vordering onbepaald & 21.994 & 168 & 1.946 & 408 \\
Totaal & 397.688 & 45 & 5.107 & 474 \\
\hline
\end{tabular}

${ }^{a}$ Ontleend aan gegevens afkomstig van het Landelijk Dienstencentrum voor de Rechtspraak; zie ook Costello e.a. 2020.

deze zaken hebben we de procedure in eerste aanleg en in hoger beroep bestudeerd. Wij hebben aan de hand van de rolkaarten en uitspraken het procesverloop in kaart gebracht en onderzocht welke tijd is gemoeid met de afzonderlijke stappen in de procedure. Naar wij weten is een dergelijk empirisch onderzoek in Nederland niet eerder verricht. ${ }^{25}$

In het vervolg wordt achtereenvolgens ingegaan op: de methode en verantwoording van dit onderzoek (par. 2), de wijze waarop wij doorlooptijden meten (par. 3) en de tijd die gemoeid is met de afzonderlijke stappen in de procedure (par. 4). Wij sluiten af met enkele conclusies en aanbevelingen (par. 5).

\section{Doorlooptijden in handelszaken, vraagstelling en onderzoeksmethode}

De doorlooptijden van verschillende soorten civiele zaken lopen sterk uiteen. ${ }^{26}$ WSNP-zaken, faillissementsprocedures en beheerszaken worden bijvoorbeeld snel afgehandeld. Binnen de categorie van handelszaken bestaat een sterke correlatie tussen de doorlooptijden en het financiële belang van de zaak. ${ }^{27}$ Tabel 1 bevat een overzicht dat ziet op zowel kantonzaken als zaken voor de civiele kamer. Het gaat hierbij om verstekzaken en zaken op tegenspraak.

Het aantal zaken in eerste aanleg neemt sterk af met de omvang van de vordering. De doorlooptijden daarentegen

25. Min of meer vergelijkbaar empirisch onderzoek is wel al een enkele keer verricht in het buitenland. Zie bijv. S. Bielen \& W. Marneffe, 'Are courts to blame for delays in Belgian civil procedures? A decomposition of case duration', Justice System Journal (38) 2017, p. 399-420.

26. De Rechtspraak, Kengetallen gerechten 2018, par. 3.2 .

27. Zie F. van Dijk, Conflicten in economische ketens, Den Haag: Boom juridisch 2019, p. 35-37. nemen toe naarmate het financiële belang groter is. In hoger beroep neemt het aantal zaken eerst toe met de omvang van de vordering om daarna te dalen. De lengte van de procedures neemt toe met het financieel belang, maar minder sterk dan in eerste aanleg. In hoger beroep zijn de gemiddelde doorlooptijden eigenlijk altijd aanzienlijk langer dan één kalenderjaar. Anders gezegd: in eerste aanleg kampt een relatief kleine categorie van zaken met een groot economisch belang met lange gemiddelde doorlooptijden. In hoger beroep kampen bijna alle handelszaken met lange doorlooptijden.

Het aantal zaken met een financieel belang van meer dan $€ 1$ miljoen is klein. Het economisch belang van die zaken is echter groot. De in geld uitgedrukte som van het enorme aantal claims tussen $€ 0$ en $€ 1000$ bedraagt $€ 68$ miljoen. ${ }^{28}$ Dit bedrag valt in het niet bij de som van de claims tussen bijvoorbeeld $€ 1$ miljoen en $€ 5$ miljoen: $€ 767$ miljoen. De gezamenlijke waarde van de zaken met een belang van meer dan $€ 100$ miljoen loopt in de miljarden. ${ }^{29}$ Het voorgaande betekent geenszins dat kleine handelsvorderingen vanuit maatschappelijk of economisch perspectief onbelangrijk zijn. Zij kunnen van groot belang zijn voor de algehele betalingsmoraal. ${ }^{30}$ Daarnaast komt het een enkele keer voor dat een zaak met een klein belang een zeer grote economische impact heeft. Denk daarbij aan principiële zaken waarin een belangrijk rechtsoordeel indirecte gevolgen heeft voor vele andere economische

28. Gemiddelde per jaar over 2016, 2017 en 2018. Data Landelijk Dienstencentrum voor de Rechtspraak. Zie ook Costello e.a. 2020.

29. Het gaat om $€ 4,5$ miljard, waarbij een zestal extreme claims buiten beschouwing is gelaten ( $\$ 50$ miljard).

30. B.C.J. van Velthoven, Incassoproblemen in het licht van de rechtspraak (Department of Economics Research Memorandum 2006/02), Leiden University 2006. 
transacties. De (directe) economische impact van een zaak met een klein financieel belang en van het totaal van die zaken is over het algemeen echter geringer dan die van geschillen met een groot financieel belang.

Zaken met een groot financieel belang zijn naar ons inzicht ook geschikt als 'stresstest' voor het functioneren van het rechtssysteem. Juist in die zaken waarin het aannemelijk is dat partijen bereid zijn hoge kosten te maken om hun belangen veilig te stellen, wordt het rechtssysteem op de proef gesteld. Wij zijn daarom geïnteresseerd in zaken waarin na de uitspraak van de rechtbank wordt doorgeprocedeerd en de cumulatie van doorlooptijden die daarbij optreedt. Het gaat ons om de tijdsduur waarmee procespartijen die om grote financiële belangen strijden te maken hebben.

Wij beogen voor zaken met een groot financieel belang de volgende onderzoeksvragen te beantwoorden:

1. Hoelang duurt de volledige behandeling van handelszaken waarin appel is ingesteld vanuit het perspectief van de procespartijen vanaf de dagvaarding totdat de zaak onherroepelijk is beslist of anderszins is beëindigd?

2. Hoeveel tijd is gemoeid met de afzonderlijke stappen die in een procedure in eerste aanleg en in hoger beroep worden gezet?

Om deze vragen te beantwoorden hebben wij circa honderd handelszaken geselecteerd. Het gaat hierbij om zaken met een belang tussen de $€ 1$ miljoen en $€ 5$ miljoen waarin hoger beroep is ingesteld. Met het oog op de vergelijkbaarheid van de zaken is gekozen voor deze betrekkelijk kleine bandbreedte, waarbinnen zich een nog relatief groot aantal zaken bevindt (zie tabel 1).

Om de selectie te kunnen maken, hebben wij gebruik gemaakt van een overzicht van alle zaken met deze karakteristieken die in hoger beroep zijn afgedaan in de jaren 2017 en 2018. Het gaat daarbij in de regel dus om zaken waarin de procedure in eerste aanleg enkele jaren daarvoor was afgerond.

Bij de selectie hebben we teruggewerkt van de laatste zaak die in hoger beroep in 2018 is afgedaan, net zolang tot het aantal van 100 zaken (in de praktijk 102 in appel) werd bereikt (eind 2017). In beginsel kwam iedere zaak voor selectie in aanmerking. Wij hebben evenwel als selectiecriterium gehanteerd dat in de betreffende zaak ten minste één inhoudelijke uitspraak is gepubliceerd op www.rechtspraak.nl. ${ }^{31}$ De reden daarvoor is dat wij de gepubliceerde uitspraken wilden raadplegen om het procesverloop goed te kunnen duiden en begrijpen. Daardoor vielen zaken af. Wij hebben voorts een enkele kortgedingzaak buiten beschouwing gelaten die ten onrechte was geregistreerd als reguliere handelszaak.

De geselecteerde zaken hebben wij bestudeerd aan de hand van de (digitale) rolkaarten. ${ }^{32}$ In de rolkaarten registreren de gerechten in beginsel alle handelingen in een zaak. De

31. In één geval hebben wij een zaak geselecteerd waarvan een bruikbare uitspraak enkel beschikbaar was via een juridisch tijdschrift dat jurisprudentie publiceert.

32. Wij hebben deze rolkaarten op verzoek ontvangen van het Landelijk Dienstencentrum voor de Rechtspraak. omschrijving daarvan is echter summier. Als er bijvoorbeeld een tussenvonnis is gewezen, wordt niets of vrijwel niets geregistreerd ten aanzien van de inhoud daarvan. Wij hebben rolkaarten ontvangen van alle zaken in hoger beroep (102 zaken). Wij hebben van de meeste zaken ook een rolkaart kunnen raadplegen van de daaraan voorafgaande procedure in eerste aanleg $\left(93\right.$ zaken $\left.^{33}\right)$. Om de summiere informatie van de rolkaarten te kunnen duiden, is gebruik gemaakt van gepubliceerde uitspraken. Daarbij is een gegeven dat zeker niet alle tussenuitspraken en einduitspraken zijn gepubliceerd.

Het gemiddelde van de doorlooptijden in eerste aanleg van de zaken in onze steekproef was 692 dagen. Dat is aanzienlijk langer dan de gemiddelde doorlooptijd van de handelszaken zoals weergegeven in tabel 1. Dat komt vooral omdat alle zaken in de steekproef zijn uitgemond in een appellabel (eind)vonnis. Anders gezegd: de selectie van zaken in eerste aanleg bevat geen zaken die na een relatief kort tijdsverloop zijn geschikt of anderszins zijn geroyeerd.

In hoger beroep is de gemiddelde doorlooptijd van de zaken in onze selectie ook groter dan de gemiddelde doorlooptijd van alle zaken: 774 dagen. Dat heeft eveneens vooral te maken met de wijze waarop wij zaken hebben geselecteerd. Wij hebben bijvoorbeeld twee kortgedingzaken die ten onrechte waren geregistreerd als gewone handelszaken niet geselecteerd. Het selectievereiste dat ten minste één bruikbare uitspraak gepubliceerd moet zijn, heeft voorts ertoe bijgedragen dat wij naar verhouding minder zaken hebben geselecteerd die kort na aanbrengen in hoger beroep zijn geroyeerd.

Onze aanpak verschaft op zaaksniveau inzicht in de cumulatie van doorlooptijden in eerste en tweede aanleg. We brengen de tijdsduur van de achtereenvolgende fasen in dezelfde procedure in eerste aanleg en in appel in kaart. We kunnen daardoor de procedure bij de rechtbank en bij het hof in iedere fase, voor zover relevant, vergelijken. Een nadeel van deze aanpak is dat de gegevens uit de eerste aanleg dateren van enige jaren geleden. Het gaat daarbij bijvoorbeeld vaak om zaken die zijn afgedaan bij een eindvonnis dat is gewezen in 2015. Wij merken overigens wel op dat wij geen aanwijzingen hebben om aan te nemen dat dit tot een onjuist beeld leidt: de doorlooptijden bij de rechtbanken zijn niet of nauwelijks veranderd in de periode 2014-2019.

Aan de hand van de geregistreerde standaardtyperingen kan men de aard van de geselecteerde zaken enigszins inzichtelijk maken (zie tabel 2). Een substantieel deel daarvan ziet op overeenkomsten.

Met behulp van de rolkaarten en de gepubliceerde uitspraken hebben wij het procesverloop van de geselecteerde zaken in kaart gebracht. Meestal was het procesverloop goed te reconstrueren. In sommige zaken vergde het enig gepuzzel om uit de beschikbare gegevens precies af te leiden wat was voor-

33. In sommige gevallen bleek het niet mogelijk om de rolkaarten eenvoudig in de systemen te traceren. In enkele gevallen was de procedure bij het hof niet voorafgegaan door een procedure in eerste aanleg. 
Tabel 2 Geregistreerde zaakstypering van de geselecteerde zaken

\begin{tabular}{llr}
\hline Hoofdtypering & Nadere typering & Aantal \\
\hline Bijzondere overeenkomst & Koop en ruil & 12 \\
& Verbruiksleen & 7 \\
& Arbeidsrecht & 7 \\
& Opdracht & 5 \\
& Overig & 6 \\
Verbintenissenrecht & Onrechtmatige daad & 10 \\
& Niet bijzondere overeenkomst & 6 \\
Rechtspersonenrecht & Overig & 9 \\
& Bestuurdersaansprakelijkheid & 9 \\
Verzekeringsrecht & Overig & 1 \\
& Dekking & 2 \\
Procesrecht & Overig & 6 \\
& Schadestaat & 2 \\
Vermogensrecht & Overig & 4 \\
& Verdeling gemeenschap & 2 \\
Overig & Pand en hypotheek & $\mathbf{1 0 2}$ \\
\hline
\end{tabular}

gevallen. Om fouten zo veel mogelijk te voorkomen, is iedere zaak door twee van ons bestudeerd.

Procedures zijn zogezegd in stukjes geknipt, waarna ieder stukje is toegedeeld aan een van de volgende hoofdcategorieën: schriftelijke fase, mondelinge fase, incidenten, bewijsverrichtingen, royement, uitspraak en overig. $\mathrm{W}_{\mathrm{ij}}$ kwamen enkele twijfelgevallen tegen, zoals gevallen waarin tijd verloren ging omdat een aanvankelijk ingeplande zitting geen doorgang vond. Wij hebben dergelijke gevallen consequent behandeld aan de hand van indelingsregels. ${ }^{34}$

34. Wij noemen hier drie belangrijke deelregels. Aktewisselingen komen in verschillende fasen van de procedure voor. In beginsel wordt de tijd die gemoeid is met akten en conclusies gerekend tot de 'schriftelijke fase'. Dat is anders indien in de aanloop van een reeds ingeroosterde zitting een akte wordt ingediend ('mondelinge fase') of indien een akte (of conclusie) wordt genomen die uitsluitend ziet op een getuigenverhoor ('bewijsverrichtingen'). Zitting die geen doorgang vindt: wij hebben de tijd die gemoeid is met een zitting of enquête die geen doorgang vindt toebedeeld aan de categorie 'overig'. Tussenuitspraken: de tijd die gemoeid is met inhoudelijke tussenuitspraken wordt toebedeeld aan de categorie 'uitspraak'. Dat geldt dus niet voor tussenuitspraken die een zuiver procedureel karakter hebben. $\mathrm{Zo}_{\mathrm{o}}$ is een uitspraak waarbij een comparitie wordt bevolen aangemerkt als een zuiver procedurele uitspraak. De tijd die daarmee gemoeid is, hoort bij de 'mondelinge fase'. Evenzo wordt de tijd die is gemoeid met een korte zuiver procedurele tussenuitspraak in het kader van een deskundigenonderzoek toebedeeld aan de fase 'bewijsverrichtingen'. Tot slot wordt ook de tijd die benodigd is voor een vonnis in een incident toebedeeld aan de categorie 'incident'. 


\section{Splitsen, stapelen en rondetijden: wat meten wij?}

\subsection{Inleiding}

De officiële cijfers van de Rechtspraak meten een zaak vanaf de eerste roldatum tot het moment dat de zaak administratief wordt afgedaan. ${ }^{35}$ Deze tijdsregistratie is vanuit het perspectief van de bedrijfsvoering van de Rechtspraak alleszins te begrijpen en te rechtvaardigen. Die tijdsregistratie komt evenwel niet altijd overeen met de totale duur van de procedure.

Het Europees Hof voor de Rechten van de Mens (EHRM) zal - bezien vanuit het perspectief van de procespartijen - de gehele procedure in aanmerking nemen. Het gaat daarbij om de totale lengte vanaf het moment van de dagvaarding tot het moment dat een definitieve uitspraak is verkregen. Ook een eventuele schadestaatprocedure en eventuele executiegeschillen worden meegeteld. ${ }^{36}$

De werkelijke duur van de gehele procedure is langer dan de geregistreerde cijfers doen vermoeden. Zo markeert juridisch bezien de dagvaarding - en niet de eerste roldatum - het begin van de procedure. ${ }^{37}$ Zou men rekenen vanaf de dagvaarding, dan zouden de doorlooptijden van de zaken in onze dataset in eerste aanleg met gemiddeld 57 dagen toenemen en in hoger beroep met gemiddeld 85 dagen. ${ }^{38}$

Belangrijker is dat uit onze dataset blijkt dat lopende procedures in een groot aantal gevallen worden 'gesplitst' of 'gestapeld'. Dan worden er meerdere procedures geregistreerd die in wezen zien op hetzelfde geschil. De gerechten meten in feite de rondetijden, niet de duur van de gehele procedure. Wij lichten dit toe aan de hand van voorbeelden.

\subsection{Doorhalingen}

Het komt voor dat een zaak om wat voor reden dan ook tussentijds wordt geroyeerd. Als de zaak dan enige tijd later weer wordt opgebracht, dan begint volgens de administratieve systemen een nieuwe zaak te lopen. Anders gezegd: waar in wezen sprake is van één procedure met één lange doorlooptijd, is volgens de systemen sprake van twee procedures, elk met een korte(re) doorlooptijd.

Wij geven een voorbeeld: bij dagvaarding van 13 augustus 2013 is hoger beroep ingesteld. Nadat een van de partijen failliet gaat, wordt de zaak op 17 februari 2015 geschorst en doorgehaald. ${ }^{39}$ De zaak wordt op 25 augustus 2015 weer opge-

35. De Rechtspraak, Kengetallen gerechten 2018, p. 23.

36. Zie over het begin- en eindpunt o.m. Smits 2008, par. 5.3.2, Asser Procesrecht/Giesen 1 2015/394-396. Zie bijv. EHRM 11 oktober 2005, nr. 4773/02 (Sychev/Oekraïne) voor een voorbeeld van een zaak waarbij ook de executiefase in aanmerking is genomen.

37. Art. $125 \mathrm{Rv}$.

38. De datum van de dagvaarding wordt niet altijd geregistreerd. In veel gevallen kan men op basis van een gepubliceerde uitspraak deze wel achterhalen. In eerste aanleg ging het gemiddeld om 57 dagen $(n=22)$. In hoger beroep ging het gemiddeld om 85 dagen $(n=40)$.

39. Hof Arnhem Leeuwarden 17 februari 2015, ECLI:NL:GHARL: 2015:1285. De schorsing geschiedde op de voet van art. 29 Fw. Uiteraard zou men de complicaties vanwege het intreden van het faillissement kunnen zien als een rechtvaardiging voor ten minste een deel van de vertraging. bracht, waarna op 1 mei 2018 een eindarrest wordt gewezen. In wezen hebben we hier te maken met één procedure die liep vanaf 13 augustus 2013 tot en met 1 mei 2018 (1722 dagen). Volgens de administratie is de procedure gesplitst in twee delen. In onze dataset is het tweede gedeelte daarvan geregistreerd als een losse procedure met een doorlooptijd van 980 dagen.

Dit voorbeeld staat niet op zichzelf. ${ }^{40}$ In de dataset zijn zes zaken opgenomen die in wezen 'het tweede stuk' van één langere procedure betreffen. De relatief korte doorlooptijden in die zaken zijn het gevolg van het feit dat het voorafgaande 'eerste stuk' van de procedure was weggelaten. Het ging om forse stukken. Indien men die stukken zou meetellen, dan zou de doorlooptijd in die zes zaken gemiddeld ruim 1100 dagen extra bedragen. ${ }^{41}$ Dat zou op zichzelf de gemiddelde doorlooptijd van alle zaken in de hele dataset al met ruim twee maanden doen toenemen. In de database zijn ook zaken opgenomen die in wezen slechts het 'eerste stuk' van een procedure vormen. Het gaat om zaken die zijn doorgehaald, maar nadien weer zijn opgebracht. ${ }^{42}$

\subsection{Cassatieprocedures}

In de dataset zit een aantal zaken die zijn afgedaan met een eindarrest waartegen nadien cassatie is ingesteld. In vier zaken is het cassatieberoep verworpen, met als gevolg dat de hofuitspraak ongeveer anderhalf jaar later onherroepelijk is geworden. ${ }^{43}$ In drie andere zaken leidde een later ingesteld cassatieberoep tot vernietiging en verwijzing. Anders gezegd: de eerdere procedure in hoger beroep moest worden voortgezet. Die verwijzingsprocedures duren (kennelijk) tot op de dag van vandaag voort. Juridisch bezien is in elk van die zaken sprake van één voortgezette procedure met één lange doorlooptijd. ${ }^{44}$

40. Een ander voorbeeld: een langlopende procedure ligt tussen 4 april 2017 en 23 mei 2017 kort stil (royement). De zaak is daardoor administratief geregistreerd als twee afzonderlijke zaken: één zaak die loopt van 25 juli 2013 tot 4 april 2017 (1349 dagen) en één zaak die loopt van 23 mei 2017 tot het eindarrest van 14 augustus 2018 (448 dagen). Weer een ander voorbeeld: partijen procederen bij de rechtbank Amsterdam. $\mathrm{Na}$ een dagvaarding, conclusie van antwoord, comparitie en een nadere aktewisseling volgt een vonnis. In dat vonnis verklaart de rechter zich onbevoegd (Rb. Amsterdam 18 december 2013, ECLI:NL:RBAMS: 2013:9630). Vervolgens wordt de procedure voortgezet bij de rechtbank Noord-Holland in de stand waar deze zich bevond. In wezen is sprake van één procedure met een lange doorlooptijd. Maar in de administratie worden doorlooptijden geregistreerd als ware sprake van twee afzonderlijke zaken.

41. Voor een volledig beeld van de instantie hadden respectievelijk 365 (schatting), 742, 1071, 1398, 1534 en 1653 dagen extra moeten worden gerekend.

42. Wij hebben niet systematisch gekeken of zaken die zijn doorgehaald later weer zijn opgebracht. Wel hebben we in de database een zaak aangetroffen die volgens de administratie is beëindigd op 12 december 2017 (ambtshalve royement). De zaak is kennelijk later weer opgebracht, aangezien we een latere tussenuitspraak aantroffen (Hof 's-Hertogenbosch 22 oktober 2019, ECLI:NL:GHSHE:2019:3859). Kennelijk loopt de zaak nog altijd door.

43. De tijd tussen de eindarresten van het hof en de Hoge Raad bedroeg 430, 535 en 654 dagen.

44. Zie Asser Procesrecht/Korthals Altes \& Groen 7 2015/329 en B.T.M van der Wiel e.a., Cassatie (Burgerlijk Proces \& Praktijk nr. 20), Deventer: Wolters Kluwer 2019/381. 
Administratief is sprake van twee appelprocedures, elk met een eigen doorlooptijd: een voordat en een nadat cassatie is ingesteld.

In de dataset zitten ook vier zaken waarin in een eerder stadium cassatie werd ingesteld. Twee daarvan zijn apart geregistreerde procedures na vernietiging en verwijzing. De derde zaak betreft een zaak waarin eerst tot in cassatie is geprocedeerd over de bevoegdheid van de rechter. De laatste zaak werd ambtshalve geroyeerd nadat cassatieberoep was ingesteld tegen een tussenarrest. Dat cassatiemiddel werd vervolgens verworpen bij arrest van 29 maart 2019. Dat betekent kort gezegd dat de eerdere appelprocedure kon worden voortgezet in de stand waarin deze zich bevond. Hoewel sprake is van één appelprocedure, wordt het tweede deel daarvan administratief beschouwd als een nieuwe procedure met een eigen doorlooptijd.

\subsection{Herroeping en verzet}

In de dataset troffen wij vier voorbeelden aan van zaken waarin de rechtsmiddelen herroeping en verzet ertoe hebben geleid dat de procedure tussen partijen na het wijzen van een einduitspraak werd voortgezet. ${ }^{45}$ Het is goed mogelijk dat deze rechtsmiddelen lang na een eerdere einduitspraak worden ingesteld. In onze dataset zitten bijvoorbeeld twee arresten die zijn gewezen in een herroeppingsprocedure. Deze zijn geregistreerd als zelfstandige procedures met een doorlooptijd van respectievelijk 462 en 532 dagen. Als men de tijd zou meten vanaf het begin van de oorspronkelijke appelprocedure tot de einduitspraak in de herroepingsprocedure, dan komt men in deze zaken tot doorlooptijden van ruim 1800 en 3500 dagen. ${ }^{46}$

In de dataset zit ook één bij verstek gewezen arrest van 12 juni 2018. De procedure is geregistreerd als zelfstandige procedure met een doorlooptijd van 413 dagen. Tegen deze uitspraak is nadien verzet ingesteld. De verzetprocedure loopt (kennelijk) nog altijd door.

\subsection{Schadestaatprocedures}

Uit onze dataset blijkt dat het met enige regelmaat voorkomt dat eerst wordt geprocedeerd over de aansprakelijkheid en pas nadien over de hoogte van de schade. In de dataset treffen wij

45. In de dataset zit bijv. één zaak waarin in het voortraject een herroepingsprocedure is gevoerd. Het valt niet uit te sluiten dat nog meer herroepingsprocedures aanhangig zijn gemaakt of zullen worden gemaakt tegen einduitspraken in onze dataset.

46. Men kan overigens wel twisten over de vraag of men de duur van een herroepingsprocedure moet betrekken bij het bepalen van de redelijke termijn. Smits en Asser lijken die vraag ontkennend te beantwoorden (Smits 2008, par. 5.3.2, HR 28 maart 2014, ECLI:NL:HR:2014:736, NJ 2014/525, m.nt. P.C.E. van Wijmen en W.D.H. Asser, sub nr. 5(b). Een andere opvatting lijkt te volgen uit EHRM 9 maart 2004, NJ 2005/13 (Pitkanen/Finland): '70 The Court notes that (...) these initial proceedings cannot be separated from those which were partly reopened by the Supreme Court in 2000, ending in 2002 with a final "determination" of part of the dispute in the form of a settlement. (...). enkele zaken aan waarin het dictum van het eindarrest voorziet in schadevergoeding nader op te maken bij staat. ${ }^{47}$

In de dataset zijn ook vier schadestaatprocedures opgenomen die vooraf zijn gegaan door eerdere aansprakelijkheidsprocedures. Zo bestond één juridisch geschil uit de volgende procedurestappen: (1) beslagverlof voorzieningenrechter, (2) aansprakelijkheidsprocedure rechtbank, (3) aansprakelijkheidsprocedure hof, (4) herroepingsprocedure bij het hof, (5) schadestaatprocedure rechtbank en (6) schadestaatprocedure hof. In de dataset zijn de schadestaatprocedure in eerste aanleg en de schadestaatprocedure in hoger beroep als zelfstandig geregistreerd (respectievelijk 644 en 728 dagen). Als je zou rekenen vanaf de dag dat beslagverlof is verzocht tot de einduitspraak in hoger beroep in de schadestaatprocedure, dan blijkt dat het bijna tien jaar kostte om dit geschil te beslechten.

De drie andere schadestaatprocedures in onze dataset laten een vergelijkbaar beeld zien. In alle drie gevallen is eerst in twee instanties geprocedeerd over de aansprakelijkheid en in alle drie gevallen was daarmee een tijd gemoeid van vijf à zes jaar. In elk van deze zaken zijn de doorlooptijden van de procedures over de aansprakelijkheid en over de hoogte van de schade apart geregistreerd.

\subsection{Hoelang duren procedures?}

In onze database bedraagt de gemiddelde geregistreerde doorlooptijd in eerste aanleg en hoger beroep respectievelijk 692 en 774 dagen. Bij elkaar opgeteld is dat ongeveer vier jaar. De voorgaande voorbeelden maken duidelijk dat dergelijke cijfers geen betrouwbaar beeld schetsen van de totale lengte van de procedures vanaf de dag van de dagvaarding tot het moment dat de zaak definitief is afgedaan.

Het eerlijke antwoord op de eerste onderzoeksvraag is dat het niet bekend is hoelang de gehele procedure vanuit het perspectief van een rechtzoekende duurt. De datum van de (appel)dagvaarding wordt niet altijd geregistreerd. Er wordt ook niet geregistreerd hoeveel (delen van) procedures in wezen zien op hetzelfde geschil. Wij kunnen daardoor de totale duur van de procedures niet uitrekenen. Duidelijk is wel dat ten opzichte van de geregistreerde cijfers forse correcties benodigd zijn. Hiervan kunnen we een schatting maken.

In alle zaken zouden we de tijd tussen het uitbrengen van de dagvaarding in eerste aanleg en de eerste roldatum moeten meetellen. In onze dataset gaat het gemiddeld om 57 dagen. ${ }^{48}$ We zouden ook in alle zaken de tijd tussen de uitspraak in eerste aanleg en de datum dat de zaak in hoger beroep is geïntroduceerd, moeten meetellen. Voor de zaken in onze dataset gaat het om ongeveer 160 dagen. ${ }^{49}$ Kortom: in alle zaken leidt dit al tot een 'correctie' van ruim 200 dagen.

47. Het gaat daarbij om ten minste twee zaken. Of in die zaken een schadestaatprocedure is ingesteld en hoelang die procedure duurt, kon niet worden vastgesteld.

48. Zie voetnoot 39

49. Dit betreft het gemiddelde van 86 zaken (lees: $\mathrm{n}=86$ ). Het gemiddelde is relatief hoog, omdat het met regelmaat voorkomt dat de termijn tussen de uitspraak in eerste aanleg en het aanbrengen van de zaak in hoger beroep langer is dan een jaar. 


\section{Complicaties}

Aantal (benedengrens)

'Splitsen' van instantie i.v.m. doorhalingen

Het instellen van cassatie

Herroeping of verzet

Separaat registreren van schadestaatprocedures

Overig

${ }^{a}$ In de dataset troffen wij vier andere zaken aan die deden vermoeden dat een administratieve afdoening geenszins het einde markeerde van het geschil. Het gaat onder andere een zaak waarin tussen partijen over hetzelfde geschil twee appelprocedures liepen en partijen - zonder het geschil te beëindigen - één van deze procedures hebben doorgehaald. In een zaak leidde een tussentijds hoger beroep tegen een tussenvonnis tot een 'eindarrest', waarna de zaak in eerste aanleg is voortgezet. In (ten minste) één zaak werd een einduitspraak nadien hersteld/aangevuld (zie art. 31 en $32 \mathrm{Rv}$ ).

Wij hebben geen uitputtend onderzoek gedaan naar alle mogelijke complicaties die meebrengen dat over eenzelfde geschil meerdere opeenvolgende procedures worden gevoerd. ${ }^{50} \mathrm{Wij}$ hebben bijvoorbeeld geen onderzoek gedaan naar de vraag of de zaken in onze dataset zijn voorafgegaan door voorlopige bewijsverrichtingen of hebben geleid tot executiegeschillen. De door ons geregistreerde voorbeelden van 'splitsen' en 'stapelen' zijn in tabel 3 weergegeven. Zou men alleen voor deze zaken een correctie doorvoeren, dan zou de gemiddelde doorlooptijd van alle zaken in de hele dataset met ten minste ${ }^{51} 284$ dagen toenemen.

De gemiddelde geregistreerde doorlooptijd van de zaken in onze dataset bedraagt in eerste aanleg en hoger beroep bij elkaar ongeveer vier jaar. Op basis van de gegevens waar wij over beschikken, is de totale doorlooptijd vanuit het perspectief van de partijen aanzienlijk langer: ten minste vijf jaar en vier maanden.

4 Nadere uitsplitsing van de doorlooptijden: hoeveel tijd is gemoeid met afzonderlijke stappen in de procedure?

\subsection{Inleiding}

Zien wij af van de complicaties die hiervoor in paragraaf 3 zijn behandeld, dan kunnen de procedures in kaart worden gebracht. Aan de hand van de rolkaarten hebben wij als het ware de procedure in stukjes geknipt en ieder stukje toebedeeld aan verschillende hoofdcategorieën. In eerste aanleg beschikten wij over bruikbare gegevens van 93 zaken. De gemiddelde geregistreerde doorlooptijd was 692 dagen. In hoger beroep beschikten we over bruikbare gegevens van 102 zaken. De gemiddelde geregistreerde doorlooptijd was 774

50. Wij hebben bijv. niet gekeken in welke gevallen een procedure precies vooraf is gegaan door conservatoire beslagen, kortgedingprocedures of voorlopige bewijsverrichtingen.

51. Het werkelijke aantal ligt vermoedelijk aanzienlijk hoger. Zo hebben wij bij zaken die vermoedelijk nog doorlopen de laatste ons bekende tussenuitspraak als eindpunt gekozen. dagen. In tabel 4 zijn deze gemiddelde doorlooptijden uitgesplitst naar de door ons onderscheiden hoofdcategorieën.

In tabel 5 en 6 is weergegeven wat de gemiddelde doorlooptijd is voor iedere afzonderlijke fase, indien en voor zover deze fase zich daadwerkelijk voordoet. Daaruit blijkt bijvoorbeeld dat bewijsverrichtingen niet zo vaak voorkomen. Indien bewijs wordt geleverd, dan kost dit echter wel heel veel tijd. Uit deze tabellen komt eveneens het beeld naar voren dat de gemiddelde doorlooptijden bij de hoven langer zijn dan die bij de rechtbanken.

In de volgende paragrafen zal nader worden ingegaan op de afzonderlijke fasen.

\subsection{Schriftelijke fase}

De schriftelijke fase omvat de tijd die gemoeid is met het uitwisselen van conclusies, memories en eventuele nadere akten. ${ }^{52}$ In eerste aanleg beschikken wij over rolkaarten van 93 zaken. Wij beschikken over bruikbare gegevens over de schriftelijke fase in 92 van de 93 zaken. Al deze zaken zijn ingeleid met een dagvaarding. Vrijwel in elke zaak heeft de wederpartij een conclusie van antwoord ingediend. In de meeste zaken volgden nadere schriftelijke stukken. In ongeveer een derde van de zaken was sprake van een vordering in reconventie waarop schriftelijk werd gereageerd. In ruim een derde van de zaken zijn een re- en dupliek ingediend. Daarnaast komt het met regelmaat voor dat partijen de gelegenheid krijgen zich nog schriftelijk uit te laten over specifieke onderdelen van het geschil. In tabel 7 is een en ander weergegeven.

In 97 van de 102 appelprocedures beschikken wij over bruikbare gegevens over de schriftelijke fase (zie tabel 8). ${ }^{53}$ In

52. Slechts in enkele specifieke gevallen zijn akten of conclusies gerekend bij andere fasen van de procedure. Zo kan worden gewezen op een akte in het geding brengen of producties voorafgaand aan een comparitie of pleidooi (wordt gerekend tot de mondelinge fase) of een conclusie na enquête (wordt gerekend als onderdeel van de bewijsverrichtingen).

53. In enkele gevallen was bijv. sprake van een splitsing van één procedure, ofwel een procedure na verwijzing, hetgeen betekent dat de reguliere wisseling van stukken al had plaatsgevonden, maar daarover geen data in onze rolkaarten beschikbaar waren. 
Tabel $4 \quad$ Doorlooptijden eerste aanleg en hoger beroep uitgesplitst

\begin{tabular}{lrr}
\hline Fase & $\begin{array}{r}\text { Gemiddelde } \\
\text { eerste aanleg }\end{array}$ & $\begin{array}{r}\text { Gemiddelde } \\
\text { hoger beroep }\end{array}$ \\
\hline Schriftelijke fase & 192 dagen & $\begin{array}{r}223 \text { dagen } \\
\text { Mondelinge fase }\end{array}$ \\
Incidenten $^{\text {a }}$ & 142 dagen & 205 dagen \\
Bewijsverrichtingen & 44 dagen & 26 dagen \\
Overig & 57 dagen & 49 dagen \\
Royement & 80 dagen & 35 dagen \\
Uitspraak & n.v.t. in steekproef & 28 dagen \\
Totaal & 178 dagen & 208 dagen \\
\hline
\end{tabular}

${ }^{a}$ Wij hebben hier gewerkt met de extra tijd die het gevolg was van een incident ('nettotijd'), opdat de optelsom in de tabel klopt. Zie voor een uitleg par. 4.4 .

Tabel $5 \quad$ Eerste aanleg, gemiddelde doorlooptijd als een fase zich voordoet

\begin{tabular}{lrrr}
\hline Fase & Aantal & Mediaan & Gemiddelde \\
\hline Schriftelijke fase & 92 zaken & 154 dagen & 194 dagen \\
Mondelinge fase & 80 zaken & 146 dagen & 165 dagen \\
Incidenten & 38 zaken & 98 dagen & 139 dagen \\
Bewijsverrichtingen & 14 zaken & 336 dagen & 377 dagen \\
Overig & 20 zaken & 166 dagen & 373 dagen \\
Uitspraak & 93 zaken & 127 dagen & 178 dagen \\
\hline
\end{tabular}

elk van deze zaken is een appeldagvaarding betekend en aangebracht. Enkele zaken zijn kort nadien - vermoedelijk als gevolg van een schikking - geroyeerd. In 82 zaken is een memorie van grieven ingediend.

In de regel worden zes, tien of twaalf weken uitgetrokken voor het nemen van een conclusie of memorie. In sommige zaken gaan partijen voortvarend te werk, bijvoorbeeld doordat zij op de dag dat de zaak in hoger beroep wordt aangebracht direct een memorie van grieven indienen. De gemiddelden weergegeven in tabel 8 zijn hoog als gevolg van enkele uitschieters. Zo was de termijn benodigd voor het nemen van de memorie van grieven in acht zaken langer dan 200 dagen. Een enkele keer blijkt uit de roljournalen dat daarvoor een verklaring is, bijvoorbeeld omdat sprake is van een partij- of advocaatwissel. In de meeste gevallen blijkt echter niets anders dan dat de zaak meermaals op de rol heeft gestaan voor een conclusie of memorie zonder dat de betreffende handeling is verricht. Kennelijk wordt vaak uitstel verleend. Uit onze data kon niet worden opgemaakt in welke gevallen sprake was van een eenzijdig verzoek om uitstel of een gezamenlijk verzoek daartoe.
In eerste aanleg bevat de dagvaarding een inhoudelijke onderbouwing van de vordering. In hoger beroep wordt over het algemeen slechts een 'kale' appeldagvaarding uitgebracht. De appellant werkt zijn grieven dan pas uit in de memorie van grieven. Zoals blijkt uit tabel 8 wordt daar ruim de tijd voor genomen. ${ }^{54}$ Dit is een van de redenen waarom de schriftelijke fase in hoger beroep langer duurt dan die in eerste aanleg. De gemiddelde tijd in hoger beroep verschilt overigens per hof. ${ }^{55}$ Zo is de tijd gemoeid met het uitbrengen van een memorie van

54. Zie ook Van Os \& Smit 2016, tabel 40; de memorie van grieven werd in $20 \%$ van de gevallen direct genomen, in $14 \%$ van de gevallen binnen zes weken, in $19 \%$ van de gevallen tussen de zes weken en drie maanden, in $24 \%$ van de gevallen tussen de drie en zes maanden en in $9 \%$ van de gevallen na meer dan zes maanden.

55. Gerechtshof Amsterdam, gem. MvG: 105 dagen $(n=17)$, gem. MvA: 83 dagen $(n=17)$; gerechtshof Arnhem-Leeuwarden, gem. MvG: 171 $(n=29)$, gem. MvA: 106 dagen $(n=28)$, gerechtshof Den Haag, gem. MvG: 85 dagen $(n=15)$, gem. MvA: 122 dagen $(n=14)$ en gerechtshof 's-Hertogenbosch, gem. MvG: 99 dagen $(n=15)$, gem. MvA: 75 dagen $(n=14)$. 


\begin{tabular}{lccr}
\hline Fase & Aantal & Mediaan & Gemiddelde \\
\hline Schriftelijke fase & 86 zaken & 210 dagen & 264 dagen \\
Mondelinge fase & 67 zaken & 282 dagen & 313 dagen \\
Incidenten & 14 zaken & 162 dagen & 192 dagen \\
Bewijsverrichtingen & 10 zaken & 308 dagen & 499 dagen \\
Overig & 15 zaken & 230 dagen & 239 dagen \\
Royement & 31 zaken & 56 dagen & 93 dagen \\
Uitspraak & 75 zaken & 230 dagen & 283 dagen \\
\hline
\end{tabular}

\section{Tabel $7 \quad$ Schriftelijkestukken in eerste aanleg}

\begin{tabular}{lrcr}
\hline & Aantal $(\mathbf{n}=\mathbf{9 2})$ & Mediaan & Gemiddelde \\
\hline Conclusie van antwoord $(\mathrm{CvA})$ & 91 & 70 dagen & 73 dagen $^{\mathrm{a}}$ \\
CvA in reconventie & 29 & 105 dagen & 109 dagen $^{\mathrm{b}}$ \\
Re- en dupliek & 32 & 155 dagen & 174 dagen $^{\mathrm{c}}$ \\
Overige stukken & $30^{\mathrm{d}}$ & & \\
\hline
\end{tabular}

${ }^{a}$ Gemeten vanaf de vorige stap, meestal het aanbrengen van de zaak, maar soms een vonnis in een incident, $t / m$ de datum van indiening van de CvA.

${ }^{\mathrm{b}}$ Gemeten vanaf de vorige inhoudelijke procedurestap, meestal de CvA.

${ }^{c}$ Gemeten vanaf de vorige procedurestap, zoals de CvA of de comparitie.

${ }^{\mathrm{d}}$ Het gaat om zeer uiteenlopende nadere akten/stukken. Soms meerdere in een zaak. Het uitrekenen van gemiddelden is daarom niet heel zinvol.

grieven relatief lang bij het gerechtshof Arnhem-Leeuwarden. ${ }^{56}$

\subsection{Mondelingefase}

De mondelinge fase omvat de tijd vanaf de laatste procedurestap tot en met de dag van de zitting. In eerste aanleg betreft het bijvoorbeeld vaak de tijd tussen de conclusie van antwoord en de comparitie na antwoord. In hoger beroep gaat het meestal om de tijd tussen de memorie van antwoord (in het incidentele appel) en het pleidooi. Het omvat de tijd die benodigd is voor het inplannen van de zitting en de tijd die nadien gewacht moet worden tot de zitting plaats zal vinden. In die periode worden vaak nog producties in het geding gebracht. ${ }^{57}$

56. De gemiddelde tijd benodigd voor de memorie van grieven is bijv. het laagst in het gerechtshof Den Haag. Bij dit hof kwam het veel vaker voor dat een partij direct bij het aanbrengen van de zaak een memorie van grieven nam (lees: 0 dagen). Dat wijst erop dat verschillen niet (alleen) het gevolg zullen zijn van verschil in beleid.

57. Destijds waren in de procesreglementen regels opgenomen over de indiening van stukken voorafgaand aan de zitting. Zie voor de huidige regeling o.m. art. 87 lid 6 Rv.
Partijen hebben recht op een mondelinge behandeling, zowel in eerste aanleg als in hoger beroep. ${ }^{58} \mathrm{Zij}$ maken daar vaak gebruik van. In 80 van de 93 geanalyseerde zaken in eerste aanleg heeft ten minste één comparitie of pleidooi plaatsgevonden. Zonder enig onderscheid te maken in de mogelijke vormen van de mondelinge behandeling kost de mondelinge behandeling ongeveer 165 dagen. Een en ander is in tabel 9 nader uitgesplitst.

In hoger beroep heeft in 67 van de 102 geanalyseerde zaken minstens één mondelinge behandeling plaatsgevonden. Zonder onderscheid te maken in de vormen van de mondelinge behandeling neemt deze fase ongeveer 313 dagen in beslag. Dat is aanzienlijk langer dan in eerste aanleg. In

58. Dit volgt o.m. uit art. 6 EVRM. Zie o.m. art. 87, 131 en 134 jo. art. 353 lid 1 Rv. 


\begin{tabular}{|c|c|c|c|}
\hline & Aantal $(n=97)$ & Mediaan & Gemiddelde \\
\hline Memorie van grieven $(\mathrm{MvG})$ & 82 & 70 dagen & 123 dagen $^{a}$ \\
\hline Memorie van antwoord (MvA) & 79 & 70 dagen & 96 dagen $^{b}$ \\
\hline MvA in incidenteel appel & 33 & 70 dagen & 73 dagen $^{c}$ \\
\hline Overige stukken & $24^{\mathrm{d}}$ & & \\
\hline
\end{tabular}

${ }^{a}$ Gemeten vanaf de vorige stap, meestal het aanbrengen van de zaak, maar soms een comparitie na aanbrengen of een arrest in een incident.

${ }^{\mathrm{b}}$ Gemeten vanaf de vorige rolhandeling, meestal de MvG.

${ }^{c}$ Gemeten vanaf de vorige procedurestap, vaak de CvA of de comparitie.

${ }^{\mathrm{d}}$ Het gaat om zeer uiteenlopende nadere akten/stukken. Soms meerdere in een zaak.

Tabel 9 Mondelinge behandeling in eerste aanleg

\begin{tabular}{lccr}
\hline & Aantal (n=93) & Mediaan & Gemiddelde \\
\hline Alleen comparitie & 62 & 141 dagen & 147 dagen \\
Alleen pleidooi & 10 & 139 dagen & 143 dagen \\
Meerdere zittingen $^{\mathrm{a}}$ & 8 & 330 dagen & 332 dagen \\
Totaal & $\mathbf{8 0}$ & $\mathbf{1 4 6}$ dagen & $\mathbf{1 6 5}$ dagen \\
\hline
\end{tabular}

${ }^{a}$ Het gaat om vier zaken met een comparitie en een pleidooi, twee zaken met twee comparities, één zaak met twee pleidooien en één zaak met twee comparities en een pleidooi. In alle gevallen wordt de tijd van de afzonderlijke zittingen uitgerekend zoals hiervoor beschreven en vervolgens bij elkaar opgeteld.

Tabel 10 Mondelinge behandeling in hoger beroep

\begin{tabular}{lrrr}
\hline & Aantal (n=102) & Mediaan & Gemiddelde \\
\hline Alleen inhoudelijke comparitie & 13 & 409 dagen & 397 dagen \\
Alleen comparitie na aanbrengen & 3 & 128 dagen & 165 dagen \\
Alleen pleidooi & 45 & 233 dagen & 281 dagen \\
Meerdere zittingen $^{\mathrm{a}}$ & 6 & 364 dagen & 438 dagen \\
Totaal & $\mathbf{6 7}$ & $\mathbf{2 8 2}$ dagen & $\mathbf{3 1 3}$ dagen \\
\hline
\end{tabular}

${ }^{a}$ Het gaat hierbij om drie zaken waarin een comparitie na aanbrengen en een pleidooi plaatsvonden, twee zaken waarin een comparitie en pleidooi plaatsvonden, en één zaak waarin twee pleidooien plaatsvonden. In alle gevallen wordt de tijd per zitting uitgerekend zoals hiervoor aangegeven. Uiteindelijk worden de tijden per zitting bij elkaar opgeteld.

tabel 10 zijn de gegevens uitgesplitst naar de aard van de mondelinge behandeling.

De tabel maakt duidelijk dat er grote verschillen bestaan tussen de gerechtshoven. Dat geldt niet alleen voor de totale doorlooptijden, maar ook voor de aard van de zittingen. Zo maakt vrijwel alleen het gerechtshof Arnhem-Leeuwarden gebruik van meervoudige comparities in plaats van de meer klassieke pleidooien. ${ }^{59}$

59. Het gerechtshof Arnhem-Leeuwarden makte twaalfmaal gebruik van een reguliere meervoudige comparitie. De andere gerechtshoven samen makten slechts eenmaal gebruik van een dergelijke comparitie. Bij deze cijfers zijn comparities na aanbrengen buiten beschouwing gelaten. Er bestaat op papier een belangrijk verschil tussen comparities en pleidooien. Wij merken op dat het etiket wellicht niet altijd iets zegt over de werkelijke aard van de zitting. Wij hebben daarnaar geen onderzoek gedaan. 
Tabel 11 Mondelinge behandeling, uitgesplitst per gerechtshof

\begin{tabular}{lccr}
\hline Gerechtshof & Aantal & Mediaan & Gemiddelde \\
\hline s-Hertogenbosch & 16 & 375 dagen & 394 dagen \\
Den Haag & 12 & 206 dagen & 217 dagen \\
Arnhem-Leeuwarden & 23 & 386 dagen & 392 dagen \\
Amsterdam & 16 & 168 dagen & 189 dagen \\
Totaal & $\mathbf{6 7}$ & $\mathbf{2 8 2}$ dagen & 313 dagen \\
\hline
\end{tabular}

\section{Tabel 12 Incidenten, bewijslevering en overig in eerste aanleg}

\begin{tabular}{lrrr}
\hline Eerste aanleg & Aantal (n=93) & Mediaan & Gemiddelde \\
\hline Incidenten & 38 & 98 dagen & 139 dagen \\
Bewijslevering & 14 & 336 dagen & 377 dagen \\
Overig & 20 & 166 dagen & 373 dagen \\
\hline
\end{tabular}

Tabel 13 Incidenten, bewijslevering en overig in hoger beroep

\begin{tabular}{lccc}
\hline Hoger beroep & Aantal $(\mathbf{n}=\mathbf{1 0 2})$ & Mediaan & Gemiddelde \\
\hline Incidenten & 14 & 162 dagen & 192 dagen $^{\mathrm{a}}$ \\
Bewijslevering & 10 & 308 dagen & 499 dagen \\
Overig & 15 & 230 dagen & 239 dagen \\
\hline
\end{tabular}

${ }^{a}$ Gemeten vanaf het moment dat het incident wordt opgeworpen totdat daarop is beslist.

In eerste aanleg konden wij gezien het grote aantal rechtbanken in relatie tot de beperkte omvang van de dataset geen representatieve uitsplitsing maken per gerecht. In hoger beroep is dat wel mogelijk. Uit tabel 11 blijkt dat er verschillen bestaan tussen de hoven.

\subsection{Incidenten, bewijslevering en overig}

Het basismodel van de procedure voorziet in één schriftelijke ronde, een mondelinge behandeling en een (eind)uitspraak. In de praktijk wordt vaak van dit basismodel afgeweken. Wij hebben geregistreerd hoeveel tijd gemoeid was met de meest voorkomende aanvullende stappen: incidenten en bewijslevering. Daarnaast hebben wij geregistreerd dat een zaak gedurende enige tijd heeft stilgelegen (overig). Een en ander is in tabel 12 en 13 weergegeven.

In eerste aanleg zijn 46 incidenten in 38 verschillende zaken opgeworpen. ${ }^{60}$ In hoger beroep zijn 15 incidenten opgeworpen in 14 verschillende zaken. Als men deze gegevens legt naast bevindingen in eerdere onderzoeken, dan lijkt het zo te

60. In zeven zaken zijn twee incidenten opgeworpen. zijn dat in zaken met een groot financieel belang naar verhouding veel incidenten worden opgeworpen. ${ }^{61}$

Aan de hand van de gegevens konden wij in de meeste zaken achterhalen wat de aard van het incident was. Het gaat daarbij om veel verschillende incidenten, zoals vrijwaringsincidenten, niet-ontvankelijkheidsincidenten, voegingsincidenten, voorlopige voorzieningen, incidenten waarbij inzage in stukken werd gevorderd, incidenten waarbij zekerheidsstelling werd gevorderd, enzovoort. Hoewel de omvang van de dataset beperkt is, signaleren wij verschillen in doorlooptijden tussen de verschillende soorten incidenten. $Z_{o}$ is de gemiddelde tijd die is gemoeid met een inzage-incident groter dan de tijd die is gemoeid met een vrijwaringsincident. ${ }^{62}$

In tabel 5, 6, 12 en 13 meten wij de totale tijd die benodigd was om op de incidentele vordering te beslissen ('brutotijd'). Het is goed om op te merken dat de tijd die is gemoeid met

61. Zie bijv. Eshuis 2007, p. 171 en 353 . Destijds werd in $11 \%$ van alle contradictoire zaken in eerste aanleg een incident opgeworpen.

62. Inzage-incidenten duren gemiddeld 154 dagen $(n=8)$, vrijwaringsincidenten 70 dagen $(n=6)$. 
een incident niet altijd leidt tot een even zo lange verlenging van de doorlooptijd van de gehele procedure. De reden is - kort samengevat - dat de behandeling van een incidentele vordering in drie zaken in eerste aanleg en in twee zaken in hoger beroep (deels) gelijkliep met die van de hoofdzaak. Denk aan die gevallen waar de incidentele vordering en het verweer daarop zijn opgenomen in de dagvaarding en de conclusie van antwoord. ${ }^{63}$ We zouden ook kunnen kijken naar de extra tijd die het gevolg is van het opwerpen van een incident ('nettotijd'). De gemiddelde tijd moet dan iets naar beneden worden bijgesteld: 109 dagen in eerste aanleg en 186 dagen in hoger beroep.

Bewijslevering komt slechts in een kleine minderheid van de zaken voor. In eerste aanleg zijn in tien zaken getuigen gehoord. In drie zaken is een deskundige benoemd. Daarnaast was in één zaak sprake van zowel een getuigenverhoor als de benoeming van een deskundige. In hoger beroep zijn in zeven zaken getuigen gehoord, in twee zaken deskundigen benoemd en was in één zaak sprake van een combinatie van beide bewijsmiddelen.

De tijd die gemoeid is met bewijslevering is aanzienlijk: ongeveer één kalenderjaar. ${ }^{64}$ Deze tijd is gerekend vanaf een tussenvonnis waarbij de bewijslevering is aangezegd en omvat alle daarop volgende en daarmee samenhangende handelingen. Denk daarbij ten aanzien van het deskundigenbericht aan de akten waarbij partijen zich uitlaten over de te benoemen deskundige en de aan hem of haar voor te leggen vragen, een extra tussenvonnis waarbij de deskundige wordt benoemd, en akten waarbij partijen reageren op het (concept)rapport. Het getuigenbewijs omvat onder meer de enquête, de contra-enquête en eventuele akten of conclusies na enquête. Hoewel de omvang van de dataset op dit punt beperkt is, wijzen onze gegevens erop dat met het deskundigenbewijs meer tijd is gemoeid dan met het getuigenverhoor. ${ }^{65}$

Tot slot is zowel in eerste aanleg als in hoger beroep sprake van een restcategorie. Het gaat om gevallen waarbij wij een bepaalde tijdsperiode niet kunnen toedelen aan de door ons onderscheiden hoofdcategorieën. In de meeste gevallen gaat het om situaties waarin de zaak gedurende enige tijd stilligt. Bijvoorbeeld gevallen waarin een zitting is ingepland, maar geen doorgang vindt, of gevallen waarin de zaak tijdelijk is geschorst.

\subsection{Einduitspraak en andere wijzen van afdoening}

In alle door ons bekeken zaken in eerste aanleg is een appellabel vonnis gewezen. In bijna alle gevallen betrof het een eindvonnis (90 zaken). In enkele gevallen ging het om een tussenuitspraak waartegen hoger beroep kon worden ingesteld (3 zaken).

In hoger beroep is in 71 van de 102 zaken een eindarrest gewezen. De overige 31 zaken zijn geroyeerd en/of ambtshalve doorgehaald. Vermoedelijk zal in veel van deze zaken een

63. Zie bijv. art. 208 lid 1 Rv.

64. Dit strookt met eerder onderzoek. Zie bijv. Van Os \& Smit 2016, p. 68.

65. Dit strookt met eerder onderzoek. Zie bijv. Eshuis 2007, p. 289. regeling zijn getroffen tussen de procespartijen. In deze 31 overige zaken was enige tijd verstreken tussen de laatste inhoudelijke proceshandeling en het moment dat de zaak werd doorgehaald. De gemiddelde tijd bedroeg 93 dagen. ${ }^{66}$

In de zaken in onze dataset worden veel uitspraken gewezen. Wij hebben deze uitspraken onderverdeeld in zuiver procedurele tussenuitspraken, uitspraken in een incident, inhoudelijke tussenuitspraken en einduitspraken. Bij zuiver procedurele uitspraken kan worden gedacht aan een kort vonnis waarin een comparitie wordt bevolen. Bij inhoudelijke tussenuitspraken kan worden gedacht aan een tussenvonnis waarin de rechter gedetailleerd ingaat op de stellingen van partijen en hun vervolgens de gelegenheid geeft bewijs te leveren of zich nog over een specifieke kwestie uit te laten. ${ }^{67}$

In tabel 14 is weergegeven hoeveel uitspraken zijn gewezen. De gegevens in eerste aanleg en hoger beroep zijn in zoverre lastig te vergelijken dat in eerste aanleg per definitie een appellabel vonnis is gewezen. In hoger beroep is een substantieel deel van de zaken relatief kort na aanbrengen geroyeerd. Om die reden zijn in de laatste kolom ter vergelijking separaat de zaken weergegeven die in hoger beroep zijn geëindigd met een eindarrest.

Wij hebben de tijd die is gemoeid met het wijzen van een inhoudelijke uitspraak los geregistreerd. De tijd die is gemoeid met het wijzen van de andere uitspraken hebben wij ondergebracht in de hiervoor reeds besproken categorieën. Zo makt een louter procedureel tussenvonnis waarin een comparitie wordt bevolen onderdeel uit van de 'mondelinge fase' en wordt een vonnis dat is gewezen in een incident gerekend tot de 'incidentfase'. De scheidslijn tussen enerzijds procedurele tussenuitspraken en anderzijds inhoudelijke tussenuitspraken is niet altijd eenvoudig te trekken. Vaak wordt aan het einde van een lange inhoudelijke tussenuitspraak immers tevens een procedurele instructie gegeven. Dergelijke uitspraken hebben wij als inhoudelijke tussenuitspraken aangemerkt.

De tijd die is gemoeid met een inhoudelijk tussenarrest of een eindarrest meten wij vanaf de laatste vorige inhoudelijke proceshandeling tot en met de datum waarop de uitspraak is gewezen. De laatste inhoudelijke proceshandeling voorafgaand aan de uitspraak in hoger beroep is meestal het pleidooi. In eerste aanleg gaat het vaak om de comparitie of de conclusie van dupliek. ${ }^{68}$

66. Het gaat om de tijd tussen de laatste inhoudelijke proceshandeling tot het moment dat de zaak is doorgehaald.

67. Bij het maken van deze indeling hebben wij gekeken naar de inhoud van de uitspraak, niet alleen naar het dictum. Het gaat dus niet alleen om deeluitspraken in de juridisch technische zin.

68. Een voorbeeld: in eerste aanleg wordt op 26 januari 2016 een comparitie gehouden, waarna op 13 april 2016 een tussenvonnis wordt gewezen. Het tussenvonnis bevat een inhoudelijk oordeel over een aantal kernvragen die partijen verdeeld houden. Het vonnis biedt de partijen daarnaast de gelegenheid andere standpunten nader toe te lichten bij akte. Op 22 juni 2016 wordt de laatste akte genomen en vervolgens wordt op 11 januari 2017 een eindvonnis gewezen. Wij meten de tijd van het inhoudelijk tussenvonnis van 26 januari $2016 \mathrm{t} / \mathrm{m} 13$ april 2016 en het eindvonnis van 22 juni $2016 \mathrm{t} / \mathrm{m} 11$ januari 2017. 


\begin{tabular}{lrrr}
\hline & $\begin{array}{r}\text { Eerste aanleg alle } \\
\text { 93 zaken }\end{array}$ & $\begin{array}{r}\text { Hoger beroep alle } \\
\text { 102 zaken }\end{array}$ & $\begin{array}{r}\text { Hoger beroep 71 zaken } \\
\text { met eindarrest }\end{array}$ \\
\hline Procedurele tussenuitspraak & 84 & 35 & 24 \\
Inhoudelijke tussenuitspraak & 38 & 29 & 22 \\
Uitspraak in incident & 48 & 15 & 12 \\
Einduitspraak & 90 & 71 & 71 \\
Totaal aantal uitspraken & $\mathbf{2 2 3}$ & $\mathbf{1 3 5}$ & $\mathbf{1 2 9}$ \\
Aantal uitspraken per zaak & $\mathbf{2 , 3 9}$ & $\mathbf{1 , 3 2}$ & $\mathbf{1 , 8 2}$ \\
\hline
\end{tabular}

Tabel 15 Tussenuitspraken en einduitspraken

Eerste aanleg $(\mathbf{n}=93)$

Hoger beroep ( $n=102)$

\begin{tabular}{lrrrr} 
& Aantal & Gemiddelde & Aantal & Gemiddelde \\
\hline Alleen een einduitspraak & 70 & 131 dagen & 54 & 214 dagen \\
Einduitspraak en één of meer tussenuitspraken & 20 & 347 dagen & 17 & 441 dagen \\
Alleen één of meer tussenuitspraken & 3 & 125 dagen & 4 & 538 dagen \\
Alle zaken met een inhoudelijke uitspraak & $\mathbf{9 3}$ & $\mathbf{1 7 8}$ dagen & $\mathbf{7 5}$ & $\mathbf{2 8 3}$ dagen \\
\hline
\end{tabular}

In tabel 15 hebben wij uitgesplitst hoeveel tijd is gemoeid met het wijzen van inhoudelijke uitspraken.

Men zou wellicht kunnen denken dat het schrijven van een einduitspraak minder tijd kost indien eerder een inhoudelijke tussenuitspraak is gewezen. Het inhoudelijke werk wordt dan immers in zekere zin 'verdeeld' over twee uitspraken. De data in de door ons onderzochte zaken bieden echter geen steun voor die gedachte. De procedure duurt langer als meer uitspraken worden gewezen. Waarschijnlijk houdt het aantal tussenuitspraken verband met de complexiteit van de zaak.

Wij zien in hoger beroep slechts kleine verschillen tussen de gerechtshoven. Als wij kijken naar zaken waarin alleen een eindarrest is gewezen, dan is de gemiddelde benodigde tijd 204 dagen bij het gerechtshof's-Hertogenbosch, 209 dagen bij het gerechtshof Arnhem-Leeuwarden, 223 dagen bij het gerechtshof Amsterdam en 230 dagen bij het gerechtshof Den Haag.

\section{Analyse, conclusies en aanbevelingen}

\subsection{De geregistreerde doorlooptijden geven geen volledig beeld van de totale duur van een procedure bezien vanuit het perspectief van partijen}

De gemiddelde doorlooptijden lopen sterk uiteen. Deze bijdrage ziet op procedures met een lange gemiddelde doorlooptijd per instantie: handelszaken met een groot financieel belang. In dergelijke zaken wordt naar verhouding ook vaak een rechtsmiddel aangewend. ${ }^{69}$ Wij hebben gekeken naar zaken met een belang tussen de $€ 1$ miljoen en $€ 5$ miljoen. Volgens het zaakregistratiesysteem van de gerechten duren de door ons onderzochte zaken in eerste aanleg gemiddeld 692 dagen en in hoger beroep gemiddeld 774 dagen. Bij elkaar opgeteld is dat bijna vier jaar.

De gegevens die door de Rechtspraak worden geregistreerd, zijn vooral bedoeld voor de interne bedrijfsvoering. Zij belichten niet het perspectief van de partijen. Een belangrijke conclusie luidt dat de procedure vanuit het perspectief van partijen langer duurt dan vier jaar: gemiddeld ten minste vijf jaar en drie maanden. De eerste hoofdoorzaak is dat de geregistreerde systemen de termijn tussen het uitbrengen van de dagvaarding en de eerste roldatum, alsook de appeltermijn, niet meetellen. De tweede hoofdoorzaak is dat de gerechten slechts 'rondetijden' registreren. Het komt met regelmaat voor dat procedures worden 'gesplitst' of 'gestapeld'. In de administratieve systemen worden dan twee of meer procedures geregistreerd met afzonderlijke (korte) doorlooptijden. Vanuit het perspectief van de partijen is sprake van één lange procedure

69. Het appelpercentage loopt sterk op met het financiële belang van de vordering. Het appelpercentage wordt benaderd door het aantal zaken in appel te delen door het aantal zaken in eerste aanleg (conform tabel 1). Het appelpercentage bedraagt dan $9 \%$ voor claims tussen $€ 10.000$ en $€ 100.000,24 \%$ tussen $€ 100.000$ en $€ 1$ miljoen en $36 \%$ tussen $€ 1$ miljoen en $€ 5$ miljoen. 
over één geschil. Wij komen in onze database met enige regelmaat zaken tegen waarvan de totale doorlooptijd vanuit het perspectief van de rechtzoekende acht, negen of tien jaar bedraagt.

Dat de Rechtspraak doorlooptijden registreert voor de interne bedrijfsvoering is alleszins te rechtvaardigen. ${ }^{70} \mathrm{De}$ interne cijfers zijn echter beperkt bruikbaar als men wil beoordelen hoelang een procedure duurt vanuit het perspectief van partijen. Zij zijn ook beperkt bruikbaar als men wil beoordelen of de rechtspraak voldoet aan de minimumnormen van art. 6 EVRM. Daartoe zal men de geregistreerde cijfers eerst naar boven toe moeten bijstellen. Zoals hiervoor toegelicht gaat het vermoedelijk om forse bijstellingen, die het totaalbeeld kunnen doen kantelen. ${ }^{71}$ De data laten zien dat de doorlooptijden in een zeer substantieel aantal zaken met een groot financieel belang niet voldoen aan minimumeisen, die kunnen worden ontleend aan art. 6 EVRM. ${ }^{72}$

Wij menen dat het vanuit het perspectief van de procespartijen zinvol zou zijn als ten minste eens in de paar jaar ook de werkelijke totale doorlooptijden worden gemeten. Het is goed om over gegevens te beschikken die men langs de lat van art. 6 EVRM kan leggen. ${ }^{73}$ Daartoe zou men het moment van de dagvaarding ook in het zaaksregistratiesysteem van de rechtbanken moeten registreren en ook de appeltermijn bij de totale doorlooptijd moeten betrekken. Tot slot dient, om de totale doorlooptijd te meten, eveneens te worden geregistreerd hoeveel en welke instanties en (deel)procedures zien op hetzelfde geschil tussen dezelfde partijen. ${ }^{74}$

70. De Rechtspraak, Kengetallen gerechten 2018, par. 3.2.2; het gaat over cijfers in de periode 2013-2018. Op basis van die cijfers werd de interne norm van twee jaar in contradictoire handelszaken in eerste aanleg in circa $90 \%$ van de gevallen gehaald. In hoger beroep ligt het percentage gemiddeld net onder de $70 \%$.

71. Uiteraard kan men twisten over de vraag welke correcties men wel of niet zou moeten doorvoeren. Zoals hiervoor aangegeven is bijv. verschil van inzicht mogelijk over hoe men moet omgaan met het bijzondere rechtsmiddel herroeping.

72. Hier wordt niet al te vaak de aandacht op gevestigd, vermoedelijk omdat het om verschillende redenen niet al te vaak voorkomt dat een procespartij klachten over de overschrijding van de redelijke termijn voorlegt aan het EHRM. Van de Bunt (2019) schrijft dat tussen 2014 en 2019 ongeveer tien zaken zijn aangebracht bij het EHRM. Voor een voorbeeld daarvan, zie EHRM 3 maart 2009, NJ 2010/223, m.nt. E.A. Alkema (Voorhuis/Nederland).

73. Voor een nadere beschrijving van de juridische maatstaf, zie de literatuur en rechtspraak zoals aangehaald in o.m. voetnoot 1, 6 en 7 .

74. Dat kan bijv. door voor ieder geschil consequent en in alle instanties één zaaknummer met verschillende volgnummers te hanteren. Op die manier kan men veel eenvoudiger achterhalen wat de allereerste en allerlaatste rolhandelingen zijn. Dit is echter gemakkelijker gezegd dan gedaan: er moet op een andere manier naar geschillen gekeken worden en dat werkt door in alle relevante administratieve systemen.

\subsection{In alle fasen van de procedure is de doorlooptijd aanzienlijk langer dan gewenst}

In de literatuur wordt door veel praktijkjuristen aangegeven dat incidenten ${ }^{75}$ en bewijsverrichtingen ${ }^{76}$ bijdragen aan vertragingen. Procedurele complicaties kunnen inderdaad in specifieke zaken tot aanzienlijke vertragingen leiden. Hoe meer stappen de procedure telt, hoe langer deze immers zal duren. ${ }^{77}$ Incidenten kosten in de regel enkele maanden. Bewijsverrichtingen komen veel minder voor, maar blijken wel meer tijd te kosten: al snel meer dan één kalenderjaar. Dat is aanzienlijk langer dan wenselijk wordt geacht. ${ }^{78}$ Uit ons onderzoek blijkt dat ook in zaken met een groot financieel belang lang niet altijd sprake is van incidenten en bewijslevering. Het gevolg daarvan is dat zij slechts een beperkte bijdrage leveren aan de gemiddelde totale geregistreerde doorlooptijd van alle door ons bestudeerde zaken.

Ons onderzoek laat bovenal zien dat de gewone basisprocedure in zaken met een groot financieel belang (te) lang duurt. In tabel 16 wordt ter illustratie een vergelijking gemaakt tussen de standaardtermijnen in de rolreglementen en de werkelijke doorlooptijden in het segment van de zaken dat wij hebben onderzocht.

De cijfers doen vermoeden dat heel vaak uitstel wordt gevraagd en verkregen voor het indienen van processtukken. Advocaten en partijen zijn kennelijk over het algemeen bereid over en weer in te stemmen met uitstel. ${ }^{79} \mathrm{~W}$ at ook de precieze oorzaak moge zijn: de schriftelijke fase duurt minstens tweemaal zo lang als de standaardtermijn in de reglementen.

Voor het inroosteren van een mondelinge behandeling bevat het rolreglement geen standaardtermijn. Het rapport Doorlooptijden in beweging hanteert afhankelijk van het soort zaak een maximale termijn 'van verweer tot zitting' van 14 tot

75. Sommige auteurs constateren dat incidenten soms worden misbruikt om de zaak te vertragen. Zie bijv. Asser Procesrecht/Van Schaick 2 2016/195 en J.R. Sijmonsma, 'Het inzagerecht van artikel 843a Rv nader bezien', TvPP 2019, afl. 4, p. 103-110, p. 105. De wetgever zelf heeft destijds de incidentenregeling vormgegeven op een wijze die 'onnodig oponthoud door de toch al vertraging meebrengende incidenten [voorkomt]'. Parl Gesch. Herz. Rv, p. 318 (MvT).

76. Zie bijv. A. Hammerstein, W.D.H. Asser \& R.H. de Bock, Modernisering burgerlijk bewijsrecht, bijlage bij Kamerstuk 29279, nr. 384, p. 13.

77. Zie o.m. Eshuis 2007, p. 258 e.v. Eshuis werkt uit dat de doorlooptijden samenhangen met het procesverloop.

78. Vgl. Mendlik e.a. 2019, beschikbaar via www.rechtspraak.nl, p. 24, waarin een maximale termijn van acht maanden aanvaardbaar wordt geacht. Vgl. voor de vraag wat redelijk is ook EHRM 27 februari 1992, nr. 12088/86 (Idrocalce S.R.L./Italië), EHRM 27 februari 1992, nr. 13362/87 (Tumminelli/Italië), EHRM 6 juli 2006, nr. 41228/02 (Rivoza/Macedonië) en EHRM 3 juli 2012, nr. 28095/08 (Siwiec/Polen).

79. Eshuis 2007, p. 277 en 288: ‘(...) de "aardigheidscultuur”, waarbij de advocaat van de wederpartij een uitstelverzoek bijna automatisch steunt, [is] niet (...) doorbroken.' In de literatuur is aangegeven dat het denkbaar is dat belangen van advocaten een rol kunnen spelen. Zie bijv. M. Barendrecht e.a., De goede procesorde in beeld (Raad voor de rechtspraak, Research Memoranda 2011/1), p. 12. P.R.J. Connolly \& S. Smith, 'The litigant's perspective on delay: Waiting for the dough', Justice System Journal (8) 1983, afl. 3, p. 271-286. 


\begin{tabular}{lcr}
\hline & Standaard & Gemiddelde \\
\hline Proceshandeling eerste aanleg & & 73 dagen \\
Conclusie van antwoord & 42 dagen & 174 dagen \\
Re- en dupliek & 84 dagen & 147 dagen \\
Comparitie na antwoord & geen & 131 dagen \\
Eindvonnis & 42 dagen & 123 dagen \\
Proceshandeling hoger beroep & & 96 dagen \\
Memorie van grieven & 42 dagen & 281 dagen \\
Memorie van antwoord & 42 dagen & 214 dagen \\
Pleidooi & geen & 70 dagen \\
Eindarrest & & $2019)$
\end{tabular}

a Zie art. 2.7 en 6.5 Landelijk procesreglement in eerste aanleg voor civiele dagvaardingszaken (vóór 1 oktober 2019) en art. 2.11 en 5.6 Landelijk procesreglement voor civiele dagvaardingszaken bij de gerechtshoven (vóór 1 oktober 2019).

18 weken. ${ }^{80}$ In onze dataset ligt de gemiddelde tijd aanmerkelijk hoger: 21 weken in eerste aanleg en 40 weken in hoger beroep.

Tot slot treden ook vertragingen op bij het wijzen van de (eind)uitspraak. ${ }^{81}$ Uit onze data blijkt dat de werkelijke tijd die daarmee gemoeid is ongeveer driemaal langer is dan de standaardtermijn die is opgenomen in de rolreglementen. ${ }^{82}$

De conclusie luidt dat de lange duur van procedures met een groot financieel belang niet primair het gevolg is van een zeer groot aantal procedurestappen. Bij de vorige grote stelselherziening van het procesrecht heeft men met enig succes geprobeerd zo veel mogelijk aanvullende stappen te schrappen. ${ }^{83} \mathrm{De}$ lange duur van de procedure is vooral het gevolg van het feit dat iedere stap in de procedure langer duurt dan beoogd. Uitstel lijkt de regel, voor zowel partijen en advocaten als rechters.

\subsection{Rechtbankprocedures zijn complexer dan appelprocedures, maar verlopen desondanks voortvarender}

De doorlooptijden in hoger beroep zijn langer dan die in eerste aanleg (zie tabel 1). ${ }^{84}$ Dit is ook het geval in de zaken die in

80. Mendlik e.a. 2019, p. 119 en 120 . Het rapport gaat in eerste aanleg uit van termijnen van 14 weken (enkelvoudige zaken) en 18 weken (meervoudige zaken). In hoger beroep wordt uitgegaan van 17 weken.

81. Zie bijv. Van de Bunt 2019, nr. 3 .

82. Zie ook Kamerstukken II 2014/15, 34059, nr. 3, p. 75, waaruit blijkt dat de wetgever van oordeel is dat een termijn van zes weken redelijk is.

83. Dat geldt in het bijzonder voor de re- en dupliek (Parl. Gesch. Herz. Rv, p. 6-8). Kennelijk met succes, omdat onze data laten zien dat in twee derde van de zaken met een groot financieel belang de re- en dupliek achterwege blijven.

84. Zie ook Klantwaardering Rechtspraak 2017, landelijk rapport d.d. 20 november 2017, p. 15 en 37: 'Bij rechtzoekenden en professionals scoren rechtbanken relatief hoger op de doorlooptijd, terwijl hoven en bijzondere colleges hier lager op scoren dan gemiddeld.' deze bijdrage zijn onderzocht. Ons onderzoek laat zien waar de schoen wringt. Uit de data blijkt dat in eerste aanleg (1) meer inhoudelijke schriftelijke stukken zijn uitgewisseld, (2) meer incidenten zijn opgeworpen, (3) meer bewijsverrichtingen plaatsvinden, (4) (iets) meer mondelinge behandelingen plaatsvinden en (5) meer inhoudelijke (tussen)uitspraken worden gewezen. De doorlooptijden in eerste aanleg waren desondanks in dezelfde zaken tussen precies dezelfde partijen aanzienlijk korter dan in hoger beroep. Wij signaleren ook dat er grote verschillen bestaan tussen de hoven onderling. ${ }^{85}$ Zoals blijkt uit tabel 1 hebben ook procedures met een kleiner financieel belang in hoger beroep te kampen met lange doorlooptijden.

\subsection{Hoe verder: waar valt winst te halen?}

Uit onze data komt een beeld naar voren van veelvuldig uitstel en lange doorlooptijden. Dit leidt tot meerwerk voor zowel partijen als de rechterlijke macht. ${ }^{86}$ Er zijn al vele suggesties gedaan om de doorlooptijden te bekorten. ${ }^{87}$ Zo zet het recente

85. Zie ook De Rechtspraak, Kengetallen gerechten 2018, p. 6 en 29. Zie Eshuis 2007, p. 258 e.v. Eshuis ziet verschillen tussen rechtbanken onderling die grotendeels verklaard worden door verschillen in voorraadniveau.

86. Zie Felso e.a. 2007.

87. Klantwaardering Rechtspraak 2017, landelijk rapport d.d. 20 november 2017, p. 17: 'Doorlooptijden (...) Zorg voor realistischere en kortere doorlooptijden door:

- Vooraf rekening te houden met de aard en complexiteit van de zaak.

- Voor meer communicatie en afstemming vooraf over de planning te zorgen, bijvoorbeeld tijdens de regiezitting.

- De uitspraaktermijn vaker na te komen in plaats van uit te stellen.

- Verschillende niveaus van snelheid aan te bieden op basis van de urgentie van de zaak.

- Bij de zittingsduur tijd in te plannen om direct erna de uitspraak uit te schrijven.

- Te sturen op meer continuïteit van de rechter(s) op een zaak.' 
rapport Doorlooptijden in beweging in op het hanteren van kortere en strakkere termijnen. Het gaat het bestek van deze bijdrage te buiten om de onderliggende oorzaken en oplossingen in kaart te brengen. Het terugdringen van de doorlooptijden is immers een lastige materie, waarbij verschillende actoren een rol zouden kunnen of moeten spelen: partijen, advocaten, individuele rechters, de rechterlijke organisatie, de wetgever enzovoort. De uitkomsten van deze studie maken wel duidelijk waar de problemen zitten en waar winst valt te behalen.

Zo blijkt bijvoorbeeld uit ons onderzoek dat er veel tijd zit tussen de uitspraak in eerste aanleg en de memorie van grieven. Sinds jaar en dag zijn voorstellen gedaan die ertoe strekken de appeltermijn te verkorten en/of de appellant te verplichten zijn grieven in de dagvaarding op te nemen. ${ }^{88}$ Zou men bijvoorbeeld de regel invoeren dat de appellant zijn grieven moet opnemen in de appeldagvaarding, dan zou dat leiden tot een aanzienlijke tijdsbesparing in vrijwel alle zaken. In de zaken in onze database gaat het om een gemiddelde tijdsbesparing van 123 dagen. ${ }^{89}$

Uit ons onderzoek blijkt ook dat de cumulatie van verschillende procedures over eenzelfde geschil ertoe kan leiden dat geschillen acht tot tien jaar kunnen voortslepen. Om excessen te voorkomen zou men concrete maatregelen kunnen overwegen om te voorkomen dat te veel procedures en/of instanties worden doorlopen. Denk daarbij aan verbeteringen zoals die in de nieuwe arbitragewet, waarbij in vernietigingsen herroepingsprocedures één instantie is geschrapt. Dergelijke procedures worden nu direct aanhangig gemaakt bij het gerechtshof. ${ }^{90}$ Men zou gericht kunnen kijken of dergelijke verbeteringen ook elders denkbaar zijn. Als men bijvoorbeeld een rechtsmiddelenverbod in schadestaatprocedures zou invoeren, zou dat in sommige zaken in onze dataset twee tot drie jaar schelen.

Uit ons onderzoek blijkt tot slot dat veel vertraging optreedt bij het inplannen van de zitting en het wijzen van de uitspraak. Volgens sommigen is een cultuuromslag bij juridische professionals benodigd. ${ }^{91}$ Volgens anderen spelen capaci-

88. Zie bijv. Agenda voor de appelrechtspraak 2020, 15 april 2013, beschikbaar op www.rechtspraak.nl, aanbeveling nr. 6. De agenda voorzag in een verkorting van de appeltermijn naar zes weken. Zie bijv. ook A. Hammerstein, 'Toegang tot en omvang van het hoger beroep', in: P.H.P.H.M.C. van Kempen e.a. (red.), Hoger beroep: renovatie en innovatie, Deventer: Kluwer 2014/5 en 10: 'Ik geef er de voorkeur aan dat de aanzegging van hoger beroep geschiedt bij exploot met een termijn van zes weken en dat uiterlijk zes weken later een beroepschrift moet worden ingediend.' De wetgever heeft recent nog overwogen de appellant te verplichten de grieven op te nemen in de procesinleiding (Kamerstukken II 2014/15, 34138, nr. 3, p. 6-7 en 27).

89. Wij zien geen overtuigende reden waarom een dergelijke regel - die per slot van rekening reeds wordt toegepast in verzoekschriftprocedures en in cassatie - niet zou kunnen en moeten worden ingevoerd. De wetgever heeft hier evenwel recent nog van afgezien. Zie Kamerstukken II 2014/15, 34138, nr. 3, p. 6-7 en 27.

90. Zie art. 1064a en 1068 Rv.

91. Zie reeds Eshuis 2007. teitsproblemen bij de gerechten een rol. ${ }^{92}$ Met name bij de hoven lijkt al gedurende een aantal jaar sprake van een 'wachtrij'. Een specifieke handelszaak is pas 'aan de beurt' op het moment dat andere eerder aangebrachte zaken of meer urgente zaken zijn afgehandeld. ${ }^{3}$ Wat de precieze oorzaak ook is: ons onderzoek laat zien dat nog steeds veel tijdwinst kan worden behaald als het lukt de zitting kort na de stukkenwisseling in te plannen en eerder een uitspraak te wijzen.

\subsection{Tot besluit: doorlooptijden doen ertoe}

De meeste typen rechtszaken worden in ons rechtsbestel binnen een korte termijn afgedaan. Deze bijdrage ziet op de doorlooptijden in grote handelszaken in eerste aanleg en in hoger beroep. Onze steekproef betreft zaken met een financiële claim tussen $€ 1$ en $€ 5$ miljoen waarin hoger beroep is ingesteld. Het gaat om een betrekkelijk klein aantal zaken waarvan het financiële belang dat van de vele honderdduizenden kleinere zaken verre overstijgt en die daarom voor de economie van bijzonder belang zijn. Deze grotere handelszaken kampen met lange doorlooptijden, vooral als gevolg van voortdurend uitstel, maar ook door de cumulatie van procedures. In een substantieel aantal zaken wordt daardoor niet voldaan aan de minimumeisen die voortvloeien uit art. 6 EVRM.

Wij hebben geen onderzoek gedaan naar de factoren die de doorlooptijd bepalen in zaken met een kleiner financieel belang. Mogelijk is in dergelijke zaken sprake van een ander beeld. De lange gemiddelde doorlooptijden in hoger beroep wekken echter wel de indruk dat het algehele beeld van uitstel en vertraging breder speelt. Nader onderzoek naar andere categorieën van zaken zal meer inzicht kunnen geven in de lastige materie van de doorlooptijden in civiele zaken.

De maatschappelijke en economische implicaties van lange doorlooptijden zijn groot en hebben een bredere invloed dan alleen op de zaken zelf. De lengte, complexiteit en kosten van procedures beïnvloeden immers de vraag of zaken aan de rechter worden voorgelegd. Rechtzoekenden die worden geconfronteerd met - in hun ogen - onrecht hebben verschillende opties. ${ }^{94} \mathrm{Zij}$ kunnen zich het onrecht laten welgevallen door geen actie te ondernemen of akkoord te gaan met een onredelijk schikkingsvoorstel. Zij kunnen bijvoorbeeld ook kiezen voor een minder nette vorm van eigenrichting. Naar-

92. Zie bijv. Eshuis 2007, p. 269 en 275-277, N. Goudemans, 'Achterstanden Hof Den Bosch nog altijd fors', Advocatenblad 23 juni 2016, Sylvester e.a. 2019, p. 36, waar kort wordt ingegaan op het landelijke project handelskamers hoven om de voorraden terug te dringen, en een recent persbericht van 2 maart 2020, 'Het Gerechtshof Arnhem-Leeuwarden heeft concrete stappen gezet naar tijdige rechtspraak' (www.rechtspraak.nl).

93. Die wachtrij fungeert feitelijk als rantsoeneringsmechanisme. Zie o.m. Bauw \& Van Dijk 2005, p. 50-68, hoofdstuk 4, H.S.E. Gravelle, 'Rationing trials by waiting: Welfare implications', International Review of Law and Economics (10) 1990, p. 255-270 en A.A.S. Zuckerman, 'A reform of civil procedure. Rationing procedure rather than access to justice', Journal of Law and Society (22) 1995, p. 155-188.

94. Zie o.m. Geurts \& Ter Voert 2019. Hieruit blijkt dat slechts een fractie van de geschillen leidt tot een juridische procedure. 
mate de doorlooptijden toenemen, worden dergelijke opties veel aantrekkelijker, in het bijzonder voor de partijen die niet over een lange adem en deep pockets beschikken. Dit bredere perspectief zal naar ons oordeel leidend moeten zijn en vanuit dit perspectief moet het verbeteren van de doorlooptijden een topprioriteit zijn. 